\title{
PENGARUH PENERAPAN METODE PROBLEM BASED LEARNING TERHADAP SIKAP ILMIAH DAN HASIL BELAJAR BIOLOGI SISWA KELAS VII MTS NW 01 KEMBANG KERANG
}

\section{Effect of Application of Problem Based Learning Method on Scientific Attitude and Learning Result of Biology Students Class VII MTs NW 01 Kembang Kerang}

\author{
Sri Ismiani' ${ }^{1}$ Syukri2 $^{2}$, Dwi Wahyudiati ${ }^{3}$ \\ 1,2,3 Pendidikan Biologi FITK UIN Mataram, Mataram, NTB, Indonesia \\ email: sriismiani.uinma@gmail.com
}

\begin{abstract}
This study aims to determine the effect of the application of Problem Based Learning method on the scientific attitude and learning results of $7^{\text {th }}$ grade students in MTs NW 01 Kembang Kerang towards the study materials in biology. This research is a Quasi Experiment (Pseudo-experiment) that was designed to use both Pre-test and Post-test control groups. The study samples were taken randomly from two different classes i.e. VII $\mathrm{C}$ as the experimental group and VII D as the control. The output of this study was presented in a scientific attitude of the students, analysed by descriptive test as well as the learning results of the students which were observed by unpaired T-test. The results showed that there was a significant difference in the scientific attitude of the students in the experimental class compared to the control one where the conventional method was applied. This was shown by the difference in the variance of students' attitude (86.6\% in the experimental group; $47.2 \%$ in the control). There was also a significant difference in the learning results of these students. The T-test was performed and it has been shown that the significance value was $0.019<0.05$. To summarize this study, Problem Based Learning method had a significance impact in the scientific attitude and learning results of the students, this suggested that this method can be used as an alternative technique to teach biology in school.
\end{abstract}


Keywords: Problem Based Learning, Scientific Attitude, Learning Result.

\section{PENDAHULUAN}

Pendidikan merupakan salah satu faktor penggerak kemajuan bangsa. Melalui pendidikan, generasi bangsa memiliki bekal pengetahuan untuk menjadi individu yang berkualitas, kompeten, mandiri dan unggul. Sehingga, inovasi dan pengembangan pendidikan nasional senantiasa harus terus diupayakan untuk menghasilkan manusia Indonesia yang berkualitas dalam ilmu pengetahuan dan teknologi, serta memiliki akhlak dan spiritual yang baik.

Kualitas hasil belajar sangat tergantung dari proses pembelajaran, sehingga upaya perbaikan dan pengembangan model dan metode pembelajaran mutlak dilakukan. Untuk mencapai kualitas pembelajaran yang optimal diperlukan interaksi antara guru dan murid, dimana murid juga terlibat aktif dalam proses pembelajaran. Di sisi lain, Guru sebaiknya berperan sebagai fasilitator dalam konteks menciptakan situasi belajar yang terbuka dan menyenangkan. Dengan demikian, Guru dapat mengenali potensi yang dimiliki oleh murid dan berupaya untuk mengembangkannya.

Potensi murid akan dapat dikembangkan melalui metode pembelajaran yang baik. Metode pembelajaran adalah kerangka konseptual yang berisi prosedur yang sistematik dalam mengorganisasikan pengalaman belajar untuk mencapai tujuan belajar tertentu serta berfungsi sebagai pedoman bagi para guru dalam merencanakan dan melaksanakan aktivitas belajar mengajar (Mulyono, 2011). Metode digunakan untuk merealisasikan tujuan yang ditetapkan.

Suatu metode dapat dikatakan baik apabila dalam pelaksanaannya dapat menumbuhkan keaktifan siswa dan sikap ilmiah dalam proses pembelajaran. Sikap ilmiah adalah suatu kecenderungan terhadap suatu stimulus tertentu yang selalu berorientasi pada ilmu pengetahuan dan metode ilmiah. Sikap 
ilmiah terdiri dari aspek rasa ingin tahu, aspek respek terhadap fakta atau bukti, kemauan untuk mengubah pandangan, dan berpikir kritis (Astika dkk, 2013).

Permasalahan yang dihadapi siswa adalah guru hanya menekankan pada aspek kognitif seperti memahami konsepkonsep yang dicatat untuk dihubungkan dengan kehidupan sehari-hari tanpa mengembangkan sikap ilmiah. Penanaman sikap ilmiah yang merupakan bagian aspek afektif dan akan sangat membantu siswa memahami materi belajar (Suciati dkk, 2007).

Salah satu metode pembelajaran yang dapat mengembangkan sikap ilmiah siswa dan mampu memecahkan masalah pada saat percobaan adalah metode pembelajaran berbasis masalah (problem based learning). Problem Based Learning merupakan pembelajaran dengan menghadapkan siswa pada permasalahan-permasalah praktis sebagai pijakan dalam belajar. Model pembelajaran berbasis masalah akan melibatkan siswa secara aktif karena siswa dihadapkan pada masalah yang dihadapi oleh masyarakat, salah satunya seperti pencemaran lingkungan yang akan diselesaikan melalui metode ilmiah (Made W, 2009).

Berdasarkan observasi yang dilakukan oleh peneliti di MTs NW 01 Kembang Kerang diketahui bahwa guru masih lebih berperan aktif dibandingkan siswa. Dalam proses pembelajarannya masih banyak mengalami hambatan yaitu siswa kurang aktif, siswa lebih suka diceramahi dan fasilitas pendukung pembelajaran kurang memadai. Siswa cenderung menjadi pasif karena hanya menerima pengetahuan dari guru saja dan kurang berkesempatan untuk mengembangkan kreatifitasnya, dan hal ini dapat menimbulkan rasa bosan yang pada akhirnya akan menurunkan motivasi belajar siswa, akibatnya siswa menjadi malas belajar dan berdampak pada hasil belajar yang rendah. Hal ini terbukti dari hasil nilai rata-rata ulangan harian siswa yaitu 65 . Nilai rata-rata ulangan harian tersebut masih di bawah Kriteria Ketuntasan Minimal (KKM) yang telah ditetapkan yaitu 70.

Dari uraian di atas, perlu adanya inovasi dalam metode pembelajaran di sekolah. Salah satu cara yang lebih baik dan dapat mendorong siswa untuk lebih terlibat aktif dalam proses pembelajaran dan hasil belajarnya meningkat adalah melalui 
metode pembelajaran Problem Based Learning. Oleh karena itu peneliti bermaksud untuk mengetahui pengaruh penerapan metode pembelajaran Problem Based Learning terhadap sikap ilmiah siswa dan hasil belajar siswa.

\section{METODE PENELITIAN}

Penelitian ini dilaksanakan di MTs NW 01 Kembang Kerang Tahun Ajaran 2014/2015. Populasi dalam penelitian ini adalah siswa kelas VII MTs NW 01 Kembang Kerang yang terdiri dari empat kelas yaitu kelas VIIA, VIIB, VIIC dan VIID berjumlah 98 orang. Sampel dalam penelitian ini diambil dengan teknik cluster random sampling, sehingga diperoleh sampel dari kelas VII C sejumlah 25 siswa sebagai kelas eksperimen dan 24 siswa kelas VII D sebagai kelas kontrol. Penelitian ini termasuk jenis penelitian eksperimen semu (quasi experiment). Quasi experiment digunakan karena pada penelitian ini mempunyai kelompok kontrol dengan manusia sebagai subyek penelitian sehingga tidak sepenuhnya dapat dikendalikan oleh peneliti.

Pada penelitian ini, siswa yang diperlakukan sebagai kelompok kontrol (kontrol group) adalah kelompok siswa yang dikenai metode pembelajaran konvensional, sedangkan siswa yang diperlakukan sebagai kelompok eksperimen (experimental group) adalah siswa yang dikenai metode pembelajaran Problem Based Learning. Penelitian ini menggunakan desain pretestposttest control group.

Dalam desain ini terdapat dua kelas yang dipilih secara acak, kemudian diberi pretest untuk mengetahui kemampuan awal dan postest untuk mengetahui kemampuan akhir setelah siswa kelompok eksperimen diberikan perlakuan (treatment). Instrumen pengambilan data menggunakan lembar observasi untuk mengukur sikap ilmiah siswa dan menggunakan soal-soal tes pilihan ganda tentang ciri-ciri makhluk hidup sejumlah 25 soal untuk mengukur hasil belajar siswa.

Data hasil observasi aktivitas belajar siswa dianalisis secara deskriptif. Uji t tidak berpasangan digunakan untuk melihat perbedaan pengaruh metode Problem Based Learning antara kelompok kontrol dengan kelompok eksperimen. 


\section{HASIL DAN PEMBAHASAN}

1. Sikap Ilmiah Siswa

Hasil penelitian menunjukkan bahwa kelas eksperimen mempunyai sikap ilmiah dengan kategori yang tinggi yaitu dengan persentase 86,6\%, sedangkan kelas kontrol mempunyai aktivitas dengan kategori kurang yaitu 47,2\%. Hal ini terjadi karena pada kelas eksperimen diberi perlakuan yaitu dengan Metode Problem Based Learning, dimana metode tersebut mendorong siswa untuk lebih aktif dalam kegiatan belajarnya. Data sikap ilmiah siswa secara lebih lengkap dapat dilihat pada tabel 1 berikut ini.

Tabel 1.

Hasil Observasi Sikap Ilmiah Siswa untuk Kelas Eksperimen

\begin{tabular}{|l|c|c|c|}
\hline \multirow{2}{*}{ No } & \multirow{2}{*}{ Observer } & \multicolumn{2}{|c|}{ Skor } \\
\cline { 3 - 4 } & & Kontrol & Eksperimen \\
\hline 1 & A & 9 & 15 \\
\hline 2 & B & 8 & 16 \\
\hline 3 & C & - & 14 \\
\hline 4 & D & - & 16 \\
\hline 5 & E & - & 17 \\
\hline & $\sum$ & 17 & 78 \\
\hline & Rata-rata & 8,5 & 15,6 \\
\hline
\end{tabular}

\section{Hasil Belajar Siswa}

Kedua kelompok siswa dilakukan diberi pre-test dan post-test terhadap hasil belajar. Berdasarkan tabel 2 dapat diketahui bahwa hasil belajar siswa pada kelas eksperimen lebih tinggi saat dilakukan post test, skor tertinggi 82 dan terendah 40. Rata-rata nilai postest 70,25 untuk kelas eksperimen lebih tinggi dari nilai pretest 36,66 serta melebihi KKM 70 dan untuk kelas kontrol nilai rata-rata postest 55,57 jauh lebih tinggi dari nilai pretest 46 namun belum mencapai target KKM 70. 
Tabel 2.

Hasil Belajar Pretest dan Postest

\begin{tabular}{|c|l|c|c|c|c|}
\hline No & \multirow{2}{*}{ Dekaptor } & \multicolumn{2}{|c|}{ Eksperimen } & \multicolumn{2}{c|}{ Kontrol } \\
\cline { 3 - 6 } & Pretest & $\begin{array}{c}\text { Postes } \\
t\end{array}$ & Pretest & $\begin{array}{c}\text { Postes } \\
t\end{array}$ \\
\hline 1 & Jumlah siswa & 24 & 24 & 19 & 19 \\
\hline 2 & $\begin{array}{l}\text { Skor nilai } \\
\text { tertinggi }\end{array}$ & 64 & 82 & 62 & 80 \\
\hline 3 & $\begin{array}{l}\text { Skor nilai } \\
\text { terendah }\end{array}$ & 20 & 40 & 28 & 28 \\
\hline 4 & $\begin{array}{l}\text { Nilai rata-rata } \\
(\bar{x})\end{array}$ & 36,66 & 70,25 & 46 & 55,57 \\
\hline 5 & $\begin{array}{l}\text { Varians } \\
\left(\mathrm{s}^{2}\right)= \\
\frac{\Sigma(\mathrm{x}-\bar{x}) 2}{n-1}\end{array}$ & 897.064 & 49,07 & 151,15 & 208,3 \\
& & & 7 & 7 \\
\hline
\end{tabular}

Hasil belajar biologi pada kelas eksperimen jauh lebih tinggi dibandingkan pada kelas kontrol. Hal ini disebabkan oleh pengaruh penerapan metode Problem Based Learning yang mendorong siswa untuk lebih aktif belajar. Siswa dapat dengan leluasa menggunakan kemampuan motorik, afektif, dan kognitifnya dengan baik. Model pembelajaran berbasis masalah merupakan model pembelajaran yang menuntut siswa lebih aktif dalam proses pembelajaran. Model pembelajaran ini memberikan peluang kepada siswa untuk mengkonstruksi pengetahuannya sendiri diantaranya merumuskan hipotesis, menguji hipotesis melalui percobaan dan menginformasikan hasil penyelidikan.

Penelitian yang di lakukan oleh Astika dkk. (2013), yang menganalisis pengaruh model pembelajaran berbasis masalah terhadap sikap ilmiah dan keterampilan berpikir kritis diketahui adanya peningatan hasil sikap. Hasil peningkatan sikap ilmiah yang tinggi juga diperoleh dari Penelitian Prametasari (2012), yang mengukur efektifitas penggunaan model pembelajaran berbasis masalah (problem based learning-PBL) terhadap hasil belajar IPA siswa kelas V di SD Gugus Hasanudin Salatiga. 
Sedangkan hasil uji hipotesis diketahui hasil uji $t$ tidak berpasangan dengan nilai signifikansi 0,019 kurang dari 0,05 dengan taraf signifikansi 5\%. Dari hasil penelitian ini dapat disimpulkan bahwa metode Problem Based Learning berpengaruh terhadap sikap ilmiah serta dapat meningkatkan hasil belajar siswa, sehingga dapat digunakan sebagai salah satu alternatif metode pembelajaran biologi di sekolah

\section{KESIMPULAN}

1. Terdapat pengaruh metode Problem Based Learning terhadap sikap ilmiah siswa kelas VII MTs NW 01 kembang kerang tahun pelajaran 2014/2015. Hal ini ditunjukan dari lembar observasi yang diperoleh sebanyak $86,6 \%$ kategori tinggi kelas eksperimen dan 47,2\% kategori rendah kelas kontrol.

2. Terdapat pengaruh yang signifikan $(\mathrm{p}<0,05)$ terhadap hasil belajar siswa dengan menerapkan Metode Problem Based Learning. Hal ini ditunjukan dengan uji $\mathrm{t}$ tidak berpasangan dengan nilai $\mathrm{p}=0,019$.

\section{DAFTAR PUSTAKA}

Arikanto, S. (2006). Prosedur Penelitian, Jakarta: PT Rineka Cipta.

Astika, dkk. (2013). Pengaruh Model Pembelajaran Berbasis Masalah Terhadap Sikap Ilmiah Dan Keterampilan Berfikir Kritis. Jurnal Pascasarjana Universitas Pendidikan Ganesha Singaraja Program Studi IPA. 3.

Made, W. (2009). Strategi Pembelajaran Inovatif Kontemporer, Jakarta: Bumi Aksara.

Margono. (2007). Metodologi Penelitian Pendidikan. Jakarta: PT Rineka Cipta.

Masyhuri \& Zainuddin. (2009). Metodelogi Penelitian; Pendekatan Praktis Dan Aplikatif, Bandung: PT Rafika Aditama 
Mulyasa. (2009). Kurikulum Yang Disedarhanakan Perkembangan Standar Kompetensi dan Kompetensi Dasar, Bandung: PT Remaja Rosbakarya

Mulyono. (2011). Strategi Pembelajara, Malang: Uin-Malik Press

Prametasari MD, (2011). Efektifitas Penggunaan Model Pembelajaran Berbasis Masalah (Problem Based LearningPBL) Terhadap Hasil Belajar IPA Siswa Kelas V Di SD Gugus Hasanudin Salatiga Semester II Tahun Ajaran 2011/2012.

Wina. (2011). Strategi Pembelajaran Berorientasi Standar Proses Pendidikan, Jakarta: Kencana.

Suciati, dkk. (2007). Belajar dan Pembelajaran, Jakarta : Universitas Terbuka.

Sudijono, A. (2009). Pengantar Evaluasi Pendidikan. Jakarta: Rajawali Pers.

Sugiyono. (2012). Metodologi Penelitian Kuantitatif dan Kualitatif dan $R \& D$, Bandung: CV Alfabeta.

Sukardi dkk. (2012). Pembelajaran Berbasis Masalah melalui Eksperimen dengan Laboratorium riil dan Laboratorium virtul ditinjau dari kreativitas dan gaya belajar. Jurnal Inkuiri, 1(2).

Suprijono, A. (2012). Cooperatif Learning, Yogyakarta: Pustaka Belajar.

Theresia K., (2007). Peningkatan Hasil Belajar Sains Siswa Kelas IV Sekolah Dasar, Melalui Pendekatan Pemanfaatan Sumber Daya Alam Hayati di Lingkungan Sekitar. Jurnal Pendidikan Penabur. 9. 
Pengaruh Penerapan Metode Problem Based...

Trianto. (2010). Mendesain Model Pembelajaran Inovatif-Progresif: Konsep, Landasan dan Implementasinya Pada Kurikulum Tingkat Satuam Pendidikan (KTSP). Jakarta: Kencana. 